\title{
Strategic Research of China's Foreign Trade Based on Balanced Development of Import and Export Trade
}

\author{
Dejun Yu and Feilin Luo \\ Associate professor, Dianchi College of Yunnan University \\ Lecture, Dianchi College of Yunnan University
}

Keywords: Foreign trade of china; Import and export balance; Strategic research1; The evolution and status analysis of china's foreign trade strategy

\begin{abstract}
Since the reform and opening up (1978), China's economic take-off, to a great extent, has benefited from the tremendous achievements of the development of foreign trade. China's import and export trade has experienced a leapfrog development in the past thirty-plus years since then: the total volume of foreign trade increased to 3642, 05 billions of dollars in 2011 from \$20, 64 billion in 1978 , the ratio of total trade volume in the world up to $20 \%$ from $0.78 \%$ in the corresponding period. The growth of China's foreign trade has not only made enormous contribution to its own economic and social development, but also immensely advanced its international standing and influence.
\end{abstract}

\section{The Evolution of China's Foreign Trade Strategy}

In the past thirty-plus years, China's foreign trade strategy has experienced evolution and development, with a historical achievements made in the process. Before reform and opening up, China adopted a typical import-substitution strategy under a closure condition. In the first ten years of reform and opening up, progressive opening up strategy in an exploratory way has been made by China. It's a transition period from closure to opening-up. Although, there was still a relatively high tariff and non-tariff barrier, advanced technology and investment was gradually brought in, and special economic zones and open cities etc. were set up. From 1979 to 1987, the rank of China's trade in the world increased 16 from 34, and its GDP doubled as well. Since 1988, export-oriented strategy has been the mainstream of China's foreign trade. During this period, China's accession to WTO in 2001 was an historical point, after which China has maintained a further lower tariff level, RMB exchange rate. China's associated industries and production capacity has been constantly strengthened, which promotes the release of its huge export potential, and an opening pattern in a all-round manner, multi-field, and multi-form was thus formed. Although the volume of import has been continuously extended, export-oriented strategy has been maintained due to the faster growth of export than import.

China should be proud of its booming development of import and export trade, but not neglect the fact that many problems hiding in the high speed growth. The transformation of the pattern of its economic development is urgent more than ever since the international financial crisis in 2008. As a crucial component of economic development pattern, the strategy of foreign trade should be transformed according to domestic and foreign situation, which is an opportunity and challenge to the development and modification of China's open economy, and consolidation of its large trade country.

The Status Analysis of China's Foreign Trade Strategy. Since the adoption of export-oriented foreign trade strategy, the total volume of China's foreign trade has achieved a leapfrog development. According to sheet 1, the total trade volume was US \$ 102.8 billion in 1988, 509.65 billion in 2001, 2561.63 billion in 2009, and 3642.06 billion in 2011. In the past decades, the export-oriented foreign trade has pushed FORWARD China's rapid development, accelerated its industrialization and modernization, increased its revenue, expanded its foreign exchange reserve, 
and enhanced its international standing and influence. Due to western countries continuing economic recession, China's export trade has faced up with unprecedented challenge in the post financial crisis era. Since the crisis, trade protectionism emerges frequently and competitions in the international market become more intensive, which makes China the biggest victim of it. China is the number one in the investigations of trade remedy in the world, as well as the first of anti-dump and anti-subsidy investigations for its export products in the WTO.

However, long term overdependence on export is one of the main reasons for China's trade frictions with other countries and organizations. As the "world factory", China's export currently depends on low-cost labor cost to a great extent. Without high quality of product and technological additional value, China can only win the competition in the international market through price advantage, which in turn leads to endless trade and technological barrier. Through analysis, it can be seen that China, in order to consolidate and strength its big trading nation standing, cannot make it through export-oriented economic pattern, but to carry out the development strategy of balanced import and export trade.

\section{The Necessity of China's Balanced Import and Export Trade Development in the Post Financial Crisis Era.}

Since reform and opening up, China's huge export trade potential has been released in the process, and the government energetically encourages export, which leads to its abundant foreign exchange reserves in the trade surplus along the years. In the post financial crisis era, China has faced up with severe challenge in trade, especially export, due to the world economy recession. Therefore, it's necessary and urgent for China to accelerating the trade development mode, and carries out the strategy of balanced import and export trade development.

Domestically, the Transformation of China's Economic Development Pattern Requires the Corresponding Change of Trade Development Mode. Firstly, the domestic market, resources and environment problems become more and more prominent due to long term export-oriented economic pattern. The domestic market are not satisfied with basic production and processing any more, a large number of enterprises are inspired by the desire of innovation, which requires more advanced technologies and talents from outside world. Meanwhile, China's export mainly come from manufacturing industry, long term leapfrog development has made its resources and environment unbearable. The energy consumption per unit of GDP is 2.2 times of the world average level, and carbon dioxide emissions is higher than most of the world, which runs counter to China's economic and social sustainable development strategy.

Secondly, China has attempted to seize market share thorough low price for a long term, which leads to the lower and lower price of it export products, and the utility of total factor productivity and technological sustainable upgrading obtained through export has not been achieved. Meanwhile, the excess production capacity in some industries are formed due to unreasonable industrial pattern; the unreasonable distribution system leads to insufficient domestic demand, forcing enterprises rely on overseas market demand, which furthers falling prices and forms a vicious circle.

Thirdly, China should be fully aware of the weakening advantage of low cost. All the time, the advantage of low cost in production factors, especially labor force, has been the main factor in our trade competitiveness. Even a certain time in the future, the wave of urbanization will still guarantee some extend of demographic dividend, but as the effectiveness of family planning policy, the tendency of increasing labor cost in inevitable.

Last but not least, it's widely believed in China that import trade is the main driving force of creating a large quantity of foreign exchange, and promoting economic development, which leads to growth rate in import trade slower than export, and the situation of imbalanced trade is thus formed. For China, large scale import of production means of products and high-end products will energetically push forward its industrial development and economic construction. Through 
increasing of import, import and export trade is more balanced, the traditional industrial structure can be easier broken, industrial structure upgrading and emerging industry development accelerated, and domestic consumption improved.

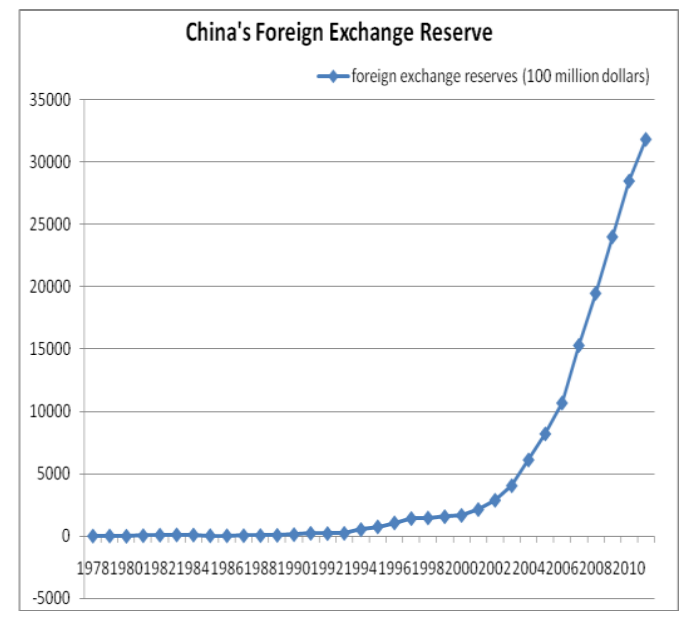

Figure 1.

Internationally, the World Economy Enters a New Period of Adjustment and Development, Requiring China's Transformation in Foreign Trade Mode. Firstly, according to studies, China's trade surplus has maintained a sustainable and steady growth rate in recent years, making up the main foreign exchange reserves in China. Vast foreign exchange reserves has played a positive role in maintaining a steady economy and providing favorable foreign trade environment, but excessive reserves will put the pressure of appreciation to RMB, and leads to China's product rise in foreign currency. Besides, huge foreign exchange reserves lead too much idle funds for China, which in turn restrains the development of productive forces to a certain extent, and impedes the development of its foreign trade.

Secondly, the total economy, trade, investment growth rate slows down relatively in the post financial crisis era, which means relatively slackening pressure of external demand for China's foreign trade. As the biggest export country in the world, the decrease of demand in international market will restrict directly China's foreign trade. Furthermore, developed countries, represented by United State of America, generally starts to pay more attention to their own manufacturing industry development, and the developing countries are also rising. All the signs mean the competition of international market will be more complex and extensive in the future.

Thirdly, with increasingly shortage of international resources, rising of trade protectionism, international trade frictions increases sharply, and China has become the biggest victim of it. According to statistics, China is now the country that has been investigated for anti-dump, anti-subsidy for most of the times. In the investigations aiming at China, there are not only lots of developed countries, but also more and more emerging economies and developing countries. Besides abuse of trade protectionism, the long term of low price strategy in China's export is responsible for it.

Lastly, the continuously deterioration of global climate will also, to a certain extent, hinder the development of developing countries. At the present stage, the developed countries play a leading role in formulation of global climate change and environment rules, thus bringing China with a lot of pressure in emission reduction and carbon transaction tax etc. As the biggest developing country, China will be restricted by environment problems in its economy. It's pressing for China to accelerate the transformation of foreign trade mode, and shake off extensive export-oriented trade mode that depends simply on processing production.

Through analysis above, it is necessary and urgent for China to accelerate the transformation of 
trade development mode, to promote the balanced development of import and export trade. To achieve the balanced development of import and export trade can effectively decrease China's huge foreign exchange reserves, and reduce trade frictions with trade partners. Meanwhile, it also means that China's idle funds will not be too much in the future; market and competitive mechanisms will be better; industrial structure will be optimized; and efficiency of resource allocation will be improved. Therefore, thorough the analysis of China's current trade situation, the expansion of import is the priority for its balanced development of import and export trade. Positively expansion of import can not only make full use of China's abundant foreign exchange resources, but also promote the optimization and upgrading of industrial structure, bring in advanced technology and equipments from developed countries, accelerate innovation process, and facilitate domestic consumption.

\section{Strategic Choices of China's Foreign Trade in the Future Based on Balanced Development of Import and Export Trade}

Since the establishment of new China, it has experienced four periods in foreign trade strategy: trade framework under unified state control, trade framework of export-oriented strategy, trade framework of import substitution, and balance between import and export. According to the status of development for the moment, China has stepped into a crucial period of building a moderately prosperous society in all aspects, which means it faces more burden in maintaining economic and social development in a sustainable way, the problems in domestic market, resources, and environment become prominent with each passing day, the way of economy development needs to be changed urgently. In order to achieve that mode of foreign trade should be transformed in time. The major task of foreign trade strategy for China is to promote the effective allocation of domestic resources and technological advance, remit trade frictions, and strengthen its speaking right in global trade. Therefore, adhering to the reform and opening up policy is still the premise of China's strategic choice, and striving to expand the import and promote the balance between import and export is the new direction in the post financial crisis era.

1. Continuing deepening reform and opening, striving to promote open economy level. The achievements made since reform and opening up indicates that it's of great importance to promote China's economic and social development, scientific and technological progress, enhance its international competitiveness and influences to use both international and domestic market and resources. As globalization furthers, it is increasingly important for the economic development of each nation to strengthen international economic and technological communication and cooperation. That means China should continuingly deepen reform and opening up, constantly improve its open economy level. In this way, it is significant to accelerate China's industrialization, urbanization, exploit broad market, constantly improve infrastructure and associated industries condition.

2. Accelerating the reform of foreign trade system, formulating systematic import and export promotion policy. For a long time, China adopted a export-oriented foreign trade policy, the importance of import has been brought to the forefront in recent years, but related import promotion policies have not been specifically formulated and put into effect. In the post financial crisis era, China should strive to build up and improve its import service platform, vigorously introduce its import laws and regulations to the outside world, set up network information platform for supply and demand, so as to create a justice equity, and open trade environment. Meanwhile, China should actively explore the construction of financial instruments, including import financing, import credit and loan, import insurance system etc., to promote the expansion of import.

3. Lowering import tariff and non-tariff barriers, striving to expand import and maintaining the balance between import and export. The import of raw materials and parts needed for export products production will be benefited from the lowering of import tariff and non-tariff barriers, so as to further promote export through import. Lowering tariff is one of the commitments made by 
China during its accession to WTO. In order to maintain the effectiveness of China's protection to its own industrial products, China, under the permission of WTO, should adopt a waterfall-style tariff structure, so that the customs duty rate will increase with domestic processing stage, namely, imposing non or low tariff to primary and semi-finished commodities, and high tariff to finished products.

4. Accelerating the technological innovation of domestic corporations so as to reduce the technology export to China from developed countries. In recent years, as some industries moving to emerging markets from the developed countries, trade protectionism from developed countries have strengthened. Developed countries have been constantly adjusting their policies on technology exportation, which has not only influenced the quality of China's import trade, but also the level of import products. Therefore, China should actively guide middle and small-sized enterprises, private enterprises to exploit import market from high and new technology industries, and formulate related policies to back it up, such as soft loan, reducing or exempting customs duty etc.

\section{References}

[1] Li Y, Xiong L. Information Services Platform of International Trade Based on E-commerce[C]// 2010 International Digital Trade and Mobile Commerce Seminar. 2010.

[2] Wei L. Construction of E-commerce Information Services Platform in International Trade [J]. Advanced Materials Research, 2014, 926-930: 2512-2515.

[3] Bao Ying, Wang Qinqin, Chen Hao et al. On the Information Management of Internet Commerce and International Trade [J] Comprehensive Digest, 2015 (9): 91-91.

[4] Zhang Baoming. E-commerce Operational Management [M]. Beijing: Tsinghua University Press, 2014. 